\title{
APPLICATION OF SOME ORGANIC ADDITIVES FOR THE MANAGEMENT OF ROOT-KNOT NEMATODE INFECTING CUCUMBER UNDER ORGANIC FARM CONDITIONS
}

\author{
Nagwa A. Abdel-Bary ${ }^{1}$, Hassan H. Hendy ${ }^{2}$, Azza H. Ashoub², \\ Mostafa Y. Yassin ${ }^{1}$ and Ghena M. Abdel-Razek ${ }^{2 *}$ \\ ${ }^{1}$ Department of Zoology and Agricultural Nematology, Faculty of \\ Agriculture, Cairo University \\ ${ }^{2}$ Department of Plant Protection, Desert Research Centre, Cairo, Egypt \\ *E-mail: ghinamamdouh@yahoo.com
}

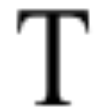

he management of the root-knot nematode, Meloidogyne incognita infecting cucumber (Cucumis sativus) roots, using the nematicidal activity of chopped fresh leaves as soil amendments such as; Metricaria chamomilla, Olea europaea, Citrus sinensis, Punica granatum, Musa paradisiaca, Datura metal, Eucalyptus globulus, Ricinus communis and Ficus benjamina under organic farm conditions was studied. The chopped fresh leaves of the tested plants were incorporated into the soil at the rate of 100 $\mathrm{g} /$ plant. Eucalyptus globulus gave the highest reduction of Meloidogyne spp. juveniles in soil as well as galls, females and eggmasses in roots since their values averaged 94.54\%, 95.04\%, $96.38 \%$ and $98.00 \%$, respectively, followed by Metricaria chamomilla after 45 days post treatment. Eucalyptus globulus still gave the most reduction and diminishing nematode numbers after 90 days. Olea europaea and Punica granatum ranked statistically in the second and third categories, respectively in number of soil juveniles. All treatments significantly improved infected cucumber growth criteria.

Keywords: Meloidogyne spp., Cucumis sativus, chopped fresh leaves, Eucalyptus globulus, soil amendments

Nematodes are among major groups of plant pathogens, and their effective control is essential for profitable production of certain crops (Halbrendt and La Mondia, 2004). Nematicides provide efficient control measure, but their use is very restricted and has been declined drastically during last few years, especially due to high toxicity to mammalians, long

The $1^{\text {st }}$ Conference of Plant Protection Science Applications for Sustainable Development of Desert Areas "Effect of Climate Change on Plant Pests and Biodiversity in Desert Environment" 19-20 October, 2019, Cairo-Egypt. 
persistence in the ecosystem, and high costs (Akhtar and Malik, 2000 and Ferraz and Freitas, 2004). Because several major nematicides have been withdrawn from the market, there is an intensive search for alternative and sustainable control measures, especially those based on the use of soil amendments with organic matter (Akhtar and Malik, 2000; Nico et al., 2004 and Cesarano et al., 2017).

The practice of adding organic matter to soil to increase yield is as old as the agriculture itself (Akhtar and Alam, 1993) and has been successfully explored to control some plant parasitic nematodes (Ferraz and Freitas, 2004). The mechanisms of nematode population reduction by soil amendments with organic matter involve stimulation of antagonistic microorganisms, liberation of secondary volatile or not-volatile phytochemicals with nematicidal properties. Besides, the amendments improve the growth of the plants and hence increase the tolerance and plant resistance to nematodes (Chavarría-Carvajal and Rodríguez-Kábana, 1998).

Cucumber (Cucumis sativus L.) is a good source of vitamins, minerals, fiber and roughage (Mukhtar et al., 2013), which is one of the reasons why it is grown all over the world. However, this popular vegetable is threatened by tremendous yield losses from Meloidogyne incognita, a nematode that attacks cucumber roots, inducing giant cell formation (Wehner et al., 1991; Walters et al., 1993 and Mukhtar et al., 2013). A clearer understanding of how $M$. incognita affects cucumber roots, the effects of infection and the associated changes in host genes expression would be of considerable value in developing strategies to prevent such attacks; however, to date such research has been limited.

Several attempts have been made by various workers for the control of plant parasitic nematodes by organic amendments (Ahmad et al., 2010; Hussain et al., 2011; Abolusoro and Abolusoro, 2012; Ahmad et al., 2013; Kimenju et al., 2014 and Zhang et al., 2019)

Therefore, the present work aims to study the nematicidal potential of chopped fresh leaves of nine plant species in reducing population density of Meloidogyne incognita under organic farm conditions.

\section{MATERIALS AND METHODS}

Greenhouse experiment was conducted to study the influence of chopped fresh leaves or peels used as soil amendments including, Metricaria chamomilla L., Olea europaea L., Citrus sinensis (L.) Osbec, Punica granatum L., Musa paradisiaca L., Datura metal, Eucalyptus globulus Labill., Ricinus communis L. and Ficus benjamina L. on galling and reproduction of Meloidogyne incognita infected cucumber (Cucumis sativus

Egyptian J. Desert Res., 69, Special Issue, 151-163 (2019) 
L.) cv. Shabah roots. A naturally infested soil with root knot nematode greenhouse $(60 \mathrm{~m} \times 12 \mathrm{~m})$ was selected in organic farm (SEKEM) for this study and cultivated with one-month old cucumber seedlings in silty clay soil with rows of $8 \mathrm{~m}$ long and the distance was $50 \mathrm{~cm}$ between the seedlings. Soil amendments were applied at rate of $100 \mathrm{~g}$ around each plant as mixed application with the upper soil. There were three replicates for each treatment and an equal number of non-treated replicates to serve as control.

All treatments were distributed in a randomized complete block design. Soil and root samples at a depth of $15-30 \mathrm{~cm}$ were taken after 45 and 90 days from adding soil amendments

Soil subsamples collected from each plant were carefully mixed and an aliquot of $200 \mathrm{~g}$ were processed for nematode extraction by sieving and Baermann-pan technique (Southey, 1970). Counts of second stage juveniles (J2) in soil were determined by means of Hawksley counting slide and stereoscopic microscope according to Siddiqui (1986). Root samples of one $\mathrm{g}$ were washed with gentle flow of tap and dried by pressing lightly between plotting papers. Then roots were cut into small pieces, mixed quiet and a given weight was processed for staining as described by Byrd et al. (1981) Also, average numbers of eggs/egg-mass were determined by hand picking four randomized selected egg-masses per each replicate. Egg-masses were shaken in $0.5 \%$ sodium hypochlorite for $2 \mathrm{~min}$ to release eggs from gelatinous matrix (Hussey and Barker, 1973). The released eggs were suspended in water and counted under stereoscopic microscope. The reduction percentage in gall formation, egg-mass production and juveniles number in soil were calculated in relative to the corresponding values of the check treatments, according to the following formula:

$\mathrm{R} \%=($ Control-Infected $) /$ Control $) \times 100$

The final population and nematode build-up were calculated for all treatments.

Final population (FP) including number of juveniles in soil + egg-masses + females.

The rate of nematode increase (FP/IP) was detected by dividing the nematode final population by the nematode initial population.

Plant growth response based on values of plant growth response as indicated by shoot length and fruit number were determined and calculated for all treatments.

Statistical analysis was carried out according to the procedure "ANOVA" as recorded by Snedecor and Cochran (1980). Means of treatments were compared by Duncan's Multiple Range Test at 5\% level of probability. These steps were accomplished using SPSS Program version 16.

Egyptian J. Desert Res., 69, Special Issue, 151-163 (2019) 


\section{RESULTS}

Through a greenhouse experiment, eight chopped fresh leaves of Eucalyptus globulus, Metricaria chamomilla, Olea europaea, Ricinus communis, Datura metal, Punica granatum, Ficus benjamina and Musa paradisiaca besides peels of Citrus sinensis at dose of $100 \mathrm{~g} /$ plant were used as soil amendments. These soil amendments were mixed with soil to determine their suppressing effect on Meloidogyne spp. infecting cucumber, Cucumis sativus. Data in table (1) show that all treatments significantly affected Meloidogyne spp. and could arrest its reproduction rate compared with check treatment after 45 days, based on reduction percentage of juveniles number, galls, females, egg-masses and eggs per egg-mass. The final population and nematode buildup were diminished that occurred with all treatments. So, a successfully gradual scale for the effectiveness of used plants can be done as follows, Eucalyptus globulus was the most effective plant followed by Metricaria chamomilla $>$ Olea europaea $>$ Citrus sinensis $>$ Ricinus communis $>$ Datura metal $>$ Punica granatum $>$ Ficus benjamina $>$ Musa paradisiaca. This scale was related with the final population reduction and nematode build-up when compared with untreated check. The highest percentage of final population reduction was achieved by Eucalyptus globulus, followed by Olea europaea since they were recorded 94.75 and $94.55 \%$. While the lowest reduction in the final population was obtained by Ficus benjamina $(71.01 \%)$. Also, the calculated rates of buildup revealed the same trend with Eucalyptus globulus. Treatment the nematode folded 0.83 vs. 24.21 folds in check treatments (Table 1). Data on response of Meloidogyne incognita infected cucumber plants to fresh chopped plant leaves as soil amendments 90 days after treatments are tabulated in table (2). Eucalyptus globulus, Olea europaea and Punica granatum were the most effective treatments, which caused significant decrement in juveniles number present in the rhizosphere $(94.54 \%, 94.54 \%$ and $92.71 \%$, respectively). The least reduction percentage in juvenile's number was presented in Musa paradisiacal $(70.90 \%)$ as well as Ficus benjamina $(70.90 \%)$ and Ricinus communis $(74.55 \%)$. A significant reduction in the galls number per gram plant was observed in Eucalyptus globulus (95.04\%), followed by Punica granatum (94.05\%), Olea europaea (92.57\%) and Musa paradisiacal (91.08). While Ricinus communis (68.81\%), Ficus benjamina (71.78\%) and Metricaria chamomilla as well as Datura metal recorded $75.24 \%$. Thus, counts of egg-masses /g of most treatments were significantly reduced than that of the check. Higher percentage reductions in egg-masses production were recorded when using Eucalyptus globules (98.00\%), Punica granatum (97\%), followed by Olea europaea $(95.00 \%)$. The lower \% reductions in egg

Egyptian J. Desert Res., 69, Special Issue, 151-163 (2019) 
APPLICATION OF SOME ORGANIC ADDITIVES

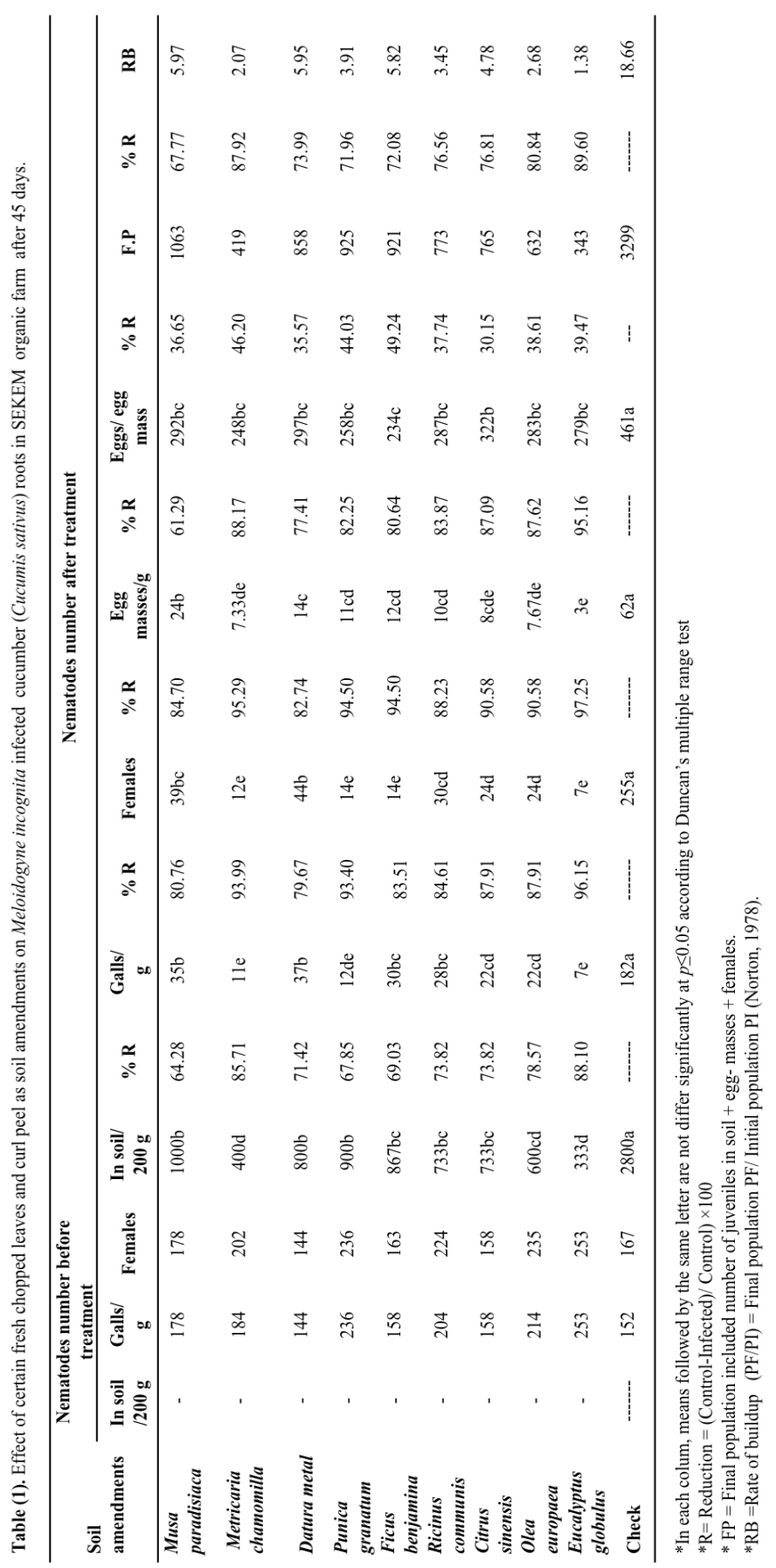

Egyptian J. Desert Res., 69, Special Issue, 151-163 (2019) 


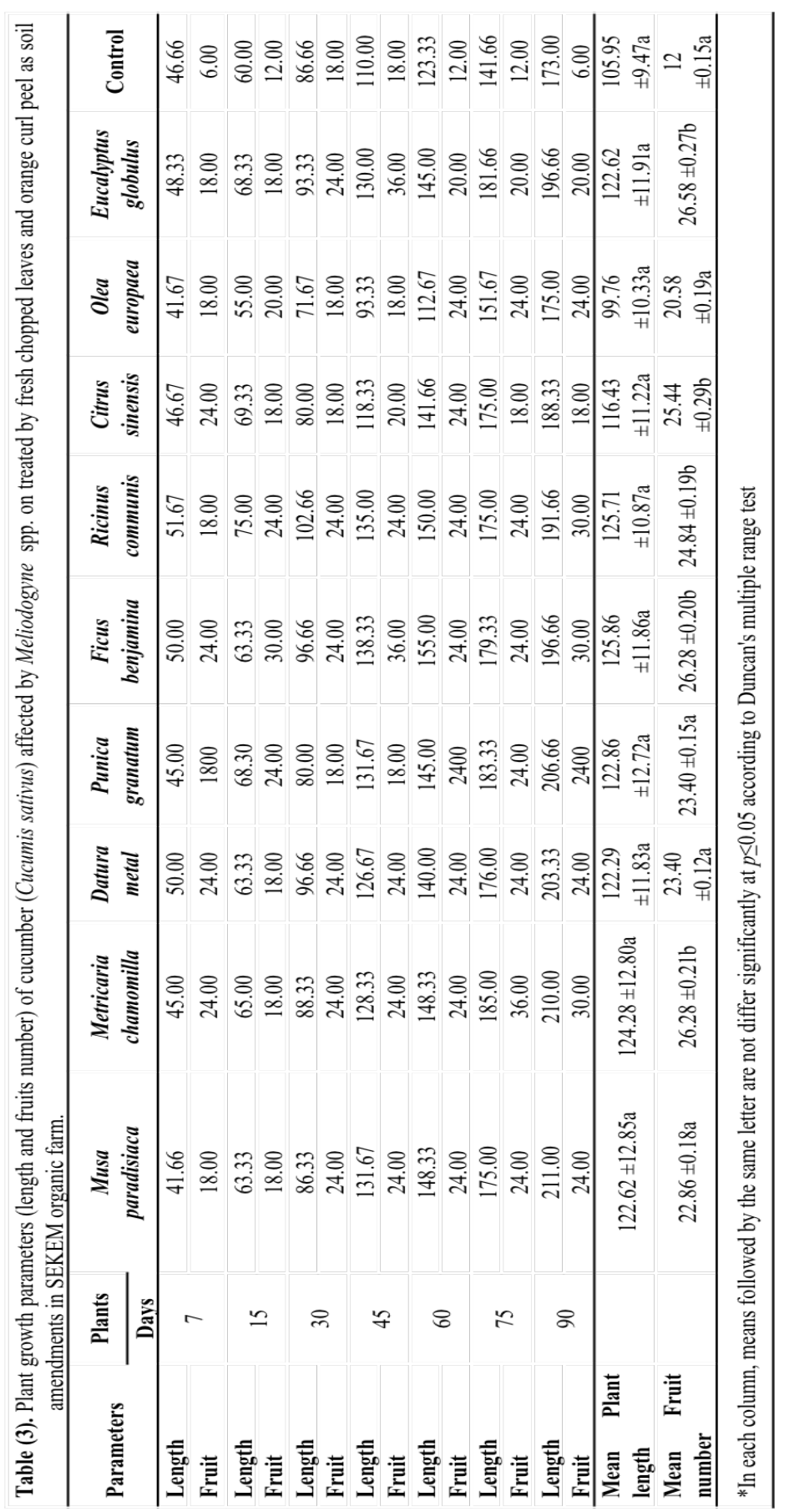

Egyptian J. Desert Res., 69, Special Issue, 151-163 (2019) 
-masses production was recorded when used Ficus benjamina (65\%), followed by Ricinus communis (77\%) and Citrus sinensis (83\%). Inhibition of egg production was more pronounced in the treatment with Ricinus communis (67.22\%), followed by Eucalyptus globulus (66.74\%). Considerable values of the nematode final population and rates of buildup were detected by all treatments. The higher final population reduction percentage was achieved by Eucalyptus globulus, followed by Olea europaea and recording $94.75 \%$ and $94.55 \%$, respectively. The lowest reduction final population was obtained by Ficus benjamina (71.01\%). Also, the calculated rates of buildup revealed the same trend in Eucalyptus globules. Treatment of the nematode folded 0.83 vs. 24.21 folds in check (Table 2).

Improvement of plant growth parameters in terms of shoot length and fruit number was variable and proportional with the tested chopped leaves of Eucalyptus globulus, Metricaria chamomilla, Olea europaea, Ricinus communis, Datura metal, Punica granatum, Ficus benjamina and Musa paradisiaca as well as peels of Citrus sinensis applied at dose of 100 $\mathrm{g} /$ plant as soil amendment (Table 3). It is interesting to notice that, plant growth parameters were highly responded to materials application, in spite of nematode infection. Although, all materials increased shoot length of treated plants, differences among values of such parameter were mostly insignificant. Musa paradisiaca and Metricaria chamomilla gave the best result in length of shoots of 211 and $210 \mathrm{~cm}$, respectively compared to check. On other hand, Olea europaea and Citrus sinensis curl peels recorded the least results of 175 and $188.33 \mathrm{~cm}$ in length of shoots. While, Metricaria chamomilla and Eucalyptus globulus gave the best results in fruits number.

\section{DISCUSSION}

The applications of organic amendments into soil led to build-up of micro-organisms, including natural enemies of nematodes. Such organic matters are known to have compounds of nematicidal effect released during its decomposition in the soil and is directly responsible for suppression of nematode population. The presence of high concentration of low molecular weight of acetic, propionic, butyric, isovaleric and valeric fatty acids as well as responsible fraction of phenols and hydrogen sulfide in the organic manure, i.e. poultry and pigeon droppings clearly proved to be highly nematotoxic (Badra et al., 1979), however ammonia, nitrites, phenols, hydrogen sulfide and wide range of volatile fatty acids and organic acids are among the chemical produced during the decomposition of plant residues and affected nematode reproduction. The high oil content of Eucalyptus

Egyptian J. Desert Res., 69, Special Issue, 151-163 (2019) 


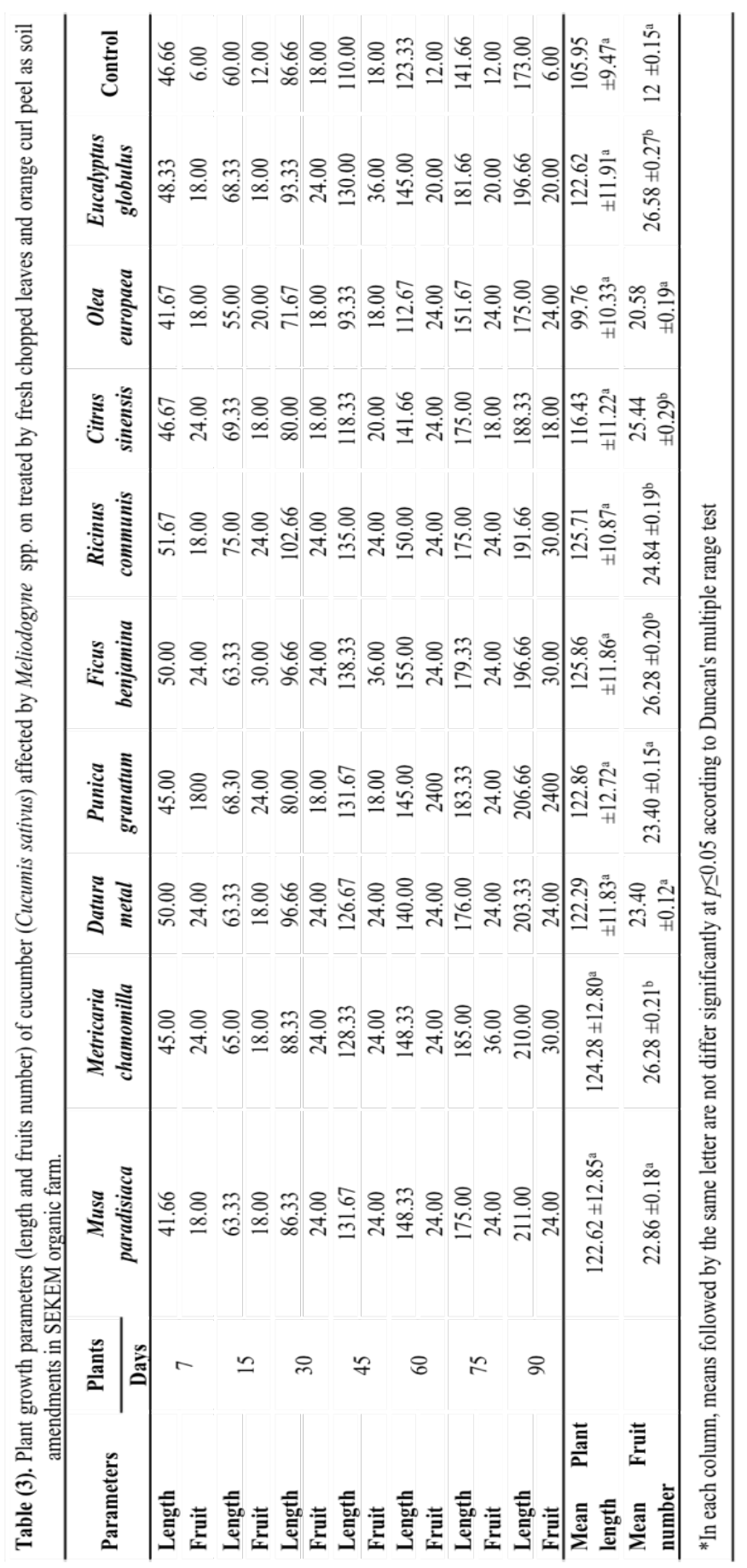

Egyptian J. Desert Res., 69, Special Issue, 151-163 (2019) 
globulus green leaves and Olea europaea may interpret its efficacy in reducing nematode reproduction (Khan et al., 1974; Mian and RodreguezKabana, 1982 and Stirling, 1991). In addition, the use of the proper organic materials to improve soil chemical, physical, and biological parameters which consequently organic matter the activities of major and minor plantparasitic nematodes in the production system. The functions and interactions of soil organic matter are complex. Some of the benefits of organic matter include the improvement of soil structure, erosion control, water relations, availability of plant nutrients, ion exchange, chelation, buffering capacity, energy for soil organisms, and suppression of plant pathogens (Hodges, 1991). Soil density affects not only root growth but also the penetration of water as well as air permeability. The addition of organic matter significantly changes soil density (Mays et al., 1973; Turner et al., 1994 and Widmer et al., 1997) by the formation and stabilization of soil aggregates (Biswas and Khosla, 1971; Pagliai et al., 1981 and Rose, 1991), which increases soil pore size (Gallardo-Lara and Nogales, 1987), that improving soil structure. Soil structure is of paramount importance in soil productivity and can become the limiting factor of crop yield (Epstein et al., 1976; Mays et al., 1973 and Rose, 1991), where the addition of organic matter can increase available water and so decrease irrigation requirements. So, moisture-holding capacity increases. Different sources of organic matter affect the chemical properties of soils through different ways. One important change resulting from the addition of organic matter is a potential increase in available nutrients, including an increase in organic carbon (Guidi et al., 1983) potassium, calcium, and magnesium (Bengston and Cornette, 1973; Mays et al., 1973 and Duggan and Wiles, 1976). Organic matter also can change the level of available nitrogen in the soil. Nitrogen availability depends on the $\mathrm{C} / \mathrm{N}$ ratio of the organic source.

\section{REFERENCES}

Abolusoro, S.A. and P.F. Abolusoro (2012). Effects of organic manure types of the growth yield as well as root and soil populations of root-knot nematodes (Meloidogyne incognita) of tomato. Scientific Journal of Agricultural, 1 (5): 138-144.

Ahmad F., M.A. Rather and M.A. Siddiqui (2010). Influence of organic additives on the incidence of root-knot nematode, Meloidogyne javanica in roots of tomato plants. Archives of Phytopathology and Plant Protection, 43 (2): 168-173.

Ahmad, F., Siddiqui, M.A. and O.O. Babalola (2013). Characterization of nematicidal activity of plant residues and their application with 
moisture approach against Meloidogyne incognita in tomato. African Journal of Agricultural Research, 8 (1): 93-101.

Akhtar, M. and M.M. Alam (1993). Utilization of waste materials in nematode control: a review. Bioresource Technology, 45 (1): 1-7.

Akhtar, M. and A. Malik (2000). Roles of organic soil amendments and soil organisms in the biological control of plant-parasitic nematodes: a review. Bioresource Technology, 74 (1): 35-47.

Badra, T., M.A. Saleh and B.A. Oteifa (1979). Nematicidal activity and composition of some organic fertilizers and amendments. Revue de Nematologie, 2: 29-30.

Bengston, G.W. and J.J. Cornette (1973). Disposal of composted municipal waste in a plantation of young slash pines: Effects on soil and trees. Journal of Environmental Quality, 2: 441-444.

Biswas, T.D. and B.K. Khosla (1971). Building up of organic matter status of the soil and its relation to the physical properties of soil. Soil Science Society of America Journal, 19: 31-37.

Byrd, D.W., T. Kirkpatrick and K.R. Barker (1983). An improved technique for cleaning and staining plant tissues for detection of nematodes. Journal of Nematology, 15: 142-143.

Chavarría-Carvajal, J.A. and R. Rodríguez-Kábana (1998). Changes in soil enzymatic activity and control of Meloidogyne incognita using four organic amendments. Nematropica, 28: 7-18.

Cesarano, G., F.D. Filippis, A.L. Storia, F. Scala and G. Bonanomi (2017). Organic amendment type and application frequency affect crop yields, soil fertility and microbiome composition. Applied Soil Ecology, 120: 254-264.

Duggan, J.C. and C.C. Wiles (1976). Effects of municipal and nitrogen fertilizer on selected soils and plants. Compost Science and Utilization, 17: 24-31.

Epstein, E., J.M. Taylor and R.L. Chaney (1976). Effects of sewage sludge and sludge compost applied to soil on some soil physical and chemical properties. Journal of Environmental Quality, 5: 422-426.

Ferraz, S. and L.G. Freitas (2004). Use of Antagonistic Plants and Natural Products. 931-978.

Gallardo-Lara, F. and R. Nogales (1987). Effect of the application of town refuse compost on the soil-plant system: A review. Biological Wastes, 19: 35-62.

Guidi, G., R. Levi-Minzi, R. Riffaldi and M. Giachetti (1983). Field trials in Italy evaluate compost and fertilizers. Biocycle, 24: 44-46.

Halbrendt, J.M. and J.A. LaMondia (2004). Crop Rotation and Other Cultural Practices. In: "Nematology, Advances and Perspectives"

Egyptian J. Desert Res., 69, Special Issue, 151-163 (2019) 
Vol. 2: Nematode Management and Utilization (Chen, Z.X., S.Y. Chen and D.W. Dickson eds.). Wallingford/Cambridge, UK: CABI Publ., p. 909-930.

Hodges, R.D. (1991). Soil Organic Matter: Its Central Position in Organic Farming. In: "Advances in Soil Organic Matter Research: The Impact on Agriculture and the Environment" (Wilson, W.S. ed.). Cambridge, UK, The Royal Society of Chemistry, p. 355-364.

Hussain, M.A., M. Tariq and M.Z. Kayani (2011). Efficacy evaluation of Azadirachta indica, Calotropis procera, Datura stramonium and Tagetes erecta against root-knot nematodes Meloidogyne incognita. Pak. J. Bot., 43: 197-204.

Hussey, R.S. and K.R Barker (1973). A comparison of methods of collecting inocula of Meloidogyne spp., including a new technique. Plant Dis. Rep., 57: 1025-1028.

Khan, A.M., M.M. Alam and R. Ahmed (1974). Mechanism of the control of plant parasitic nematodes as a result of application of oil cakes to the soil. Indian J. Nematol., 4: 93-96.

Kimenju, J.W., P.M. Wachira, J.K. Lang'at, W. Otieno and G.K. Mutua (2014). Evaluation of selected methods in the control of plant parasitic nematodes infecting carnation. Journal of Agricultural Science, 6 (3): 31-38.

Mays, D.A., G.L. Terman and J.C. Duncan (1973). Municipal compost: Effects on crop yields and soil properties. Journal of Environmental Quality, 2: 89-92.

Mukhtar T., M.Z. Kayani and M.A. Hussain (2013). Response of selected cucumber cultivars to Meloidogyne incognita. Crop Prot., 44: 1317.

Mian, I.H. and R. Rodringuz-Kabana (1982). Soil amendments with oil cakes and chicken litter for control of Meloidogyne arenaria. Nematropica, 12: 205- 220.

Norton, D.C. (1978). In: "Ecology of Plant Parasitic Nematodes". Jon Willeg and Soms. New York, $238 \mathrm{p}$.

Nico, A.I., R.M. Jimenez-Diaza and P. Castillo (2004). Control of root knot nematodes by composted agro-industrial wastes in potting mixtures. Crop Protection, 23: 581-587.

Pagliai, M., G. Guidi, M. La Marca, M. Giachetti and G. Lucamante (1981). Effects of sewage sludges and composts on soil porosity and aggregation. Journal of Environmental Quality, 10: 556-561.

Rose, D.A. (1991). The Effect of Long-continued Organic Manuring on Some Physical Properties of Soils. In: "Advances in Soil Organic Matter Research: The Impact on Agriculture and the Environment" 
(Wilson, W.S. ed.). Cambridge, UK: The Royal Society of Chemistry, p.197-205.

Snedecor, G.W. and W.G. Cochran (1980). In: "Statistical Methods". Oxford $\&$ J.BH Publishing Company, $7^{\text {th }}$ edition.

Southey, J.F. (1970). In: "Laboratory Methods for Work with Plant and Soil Nematodes". Ministry of Agriculture, Fish and Food Tech. Bulletin 2. Her Majesty's Stationery Office London,148 p.

Siddiqui, M.R. (1986). In: "Tylenchida, Parasites of Plants and Insects". Common-Wealth Agric. Bureaux, London, 645 p.

Stirlling, G.R. (1991). Biological control of plant parasitic nematodes and prospect. Redwood press LTD, Melksham, U.K.

Turner, M.S., G.A. Clark, C.D. Stanley and A.G. Smajstrla (1994). Physical characteristics of a sandy soil amended with municipal solid waste compost. Proceedings of the Soil and Crop Science, Society of Florida, 53: 24-26.

Walters, S.A., T.C. Wehner and K.R. Barkel (1993). Root-knot nematode resistance in cucumber and horned cucumber. HortScience, 28: 151154.

Wehner, T.C., S.A. Walters and K.R. Barker (1991). Resistance to root-knot nematodes in cucumber and horned cucumber. J. Nematol., 23: 611.

Widmer, T.L., J.G. Graham and D.J. Mitchell (1997). Potential use of composted municipal waste for management of Phytophthora root rot of bearing citrus. Proceedings of the Florida State Horticultural Society, 110: 46-50.

Zhang, S., S. Cui, N.B. McLaughlin, P. Liu, N. Hu, W. Liang, D. Wu and A. Liang (2019). Tillage effects outweigh seasonal effects on soil nematode community structure. Soil and Tillage Research, 192: 233239.

Egyptian J. Desert Res., 69, Special Issue, 151-163 (2019) 


\section{إستخدام بعض الإضافات العضوية كوسيلة لمكافحة نيماتودا تعقد الجذور التي

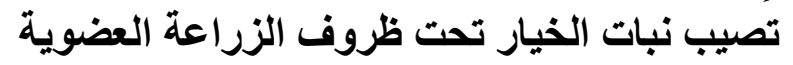 \\ نجوى عبد الحميد عبد الباري', حسن حامد هندي، عزة هاثم عثوب، مصطقى

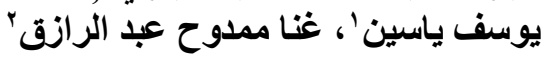

' ق قسم الحيو ان و النيماتولوجيا الزر اعية، كلية الزر اعة، جامعة القاهرة، الجيزة

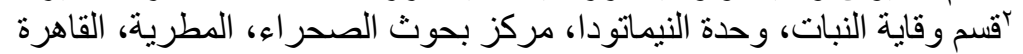

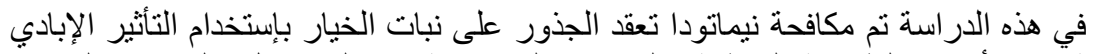

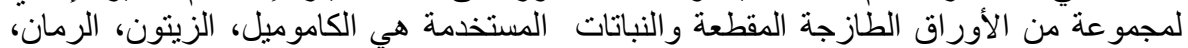

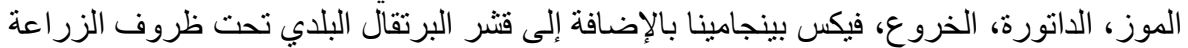

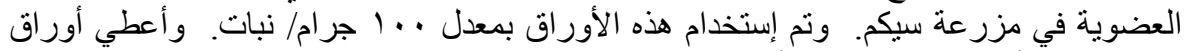

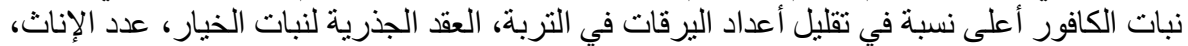

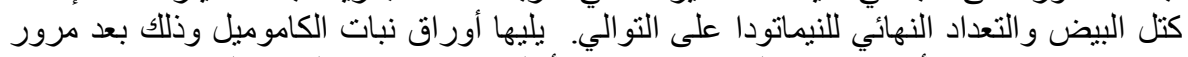

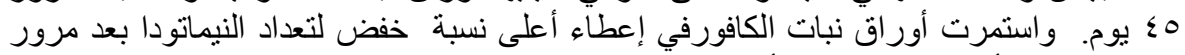

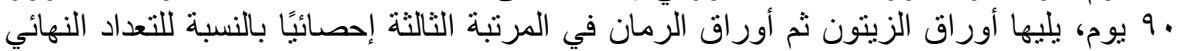

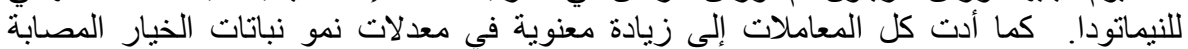
بالمقارنة بنلك المصابة و غير المعاملة. 